\title{
The effects of wireless on carbonic anhydrase and acetylcholinesterase enzyme activities in some tissues related to respiratory, excretory and reproductive systems of rats
}

\section{Wireless'in (wi-fi) boşaltim ve üreme sistemleri ille illgili bazi dokularda karbonik anhidraz ve asetilkolinesteraz enzim aktivitelerine etkileri}

\author{
Sevgi Durna Dastan¹, Parham Taslimi², Fatih Gurses ${ }^{3}$, Recep Akkaya ${ }^{4 *}$, Faik Gökalp ${ }^{5}$, \\ Illhami Gulcinn²
}

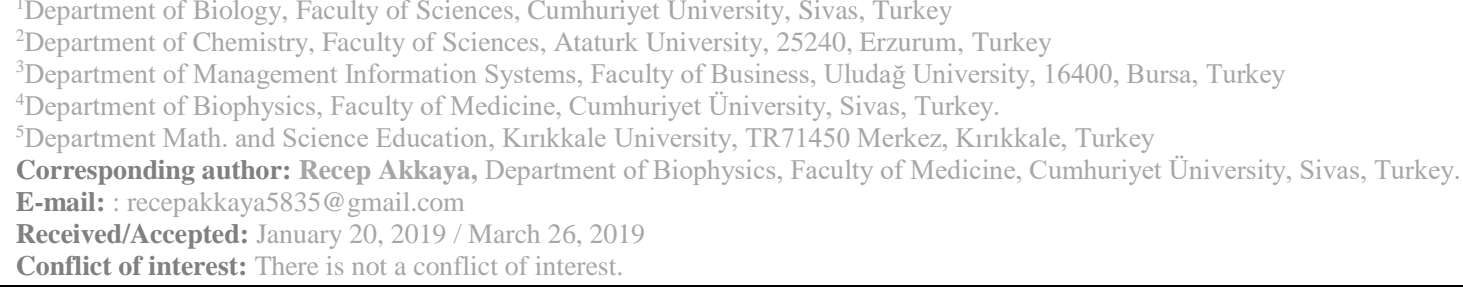

\section{SUMMARY}

The aim of our studies is to understand the effects of wireless (Wi-Fi) waves on carbonic anhydrase (CA) and acetylcholinesterase (AChE) enzyme activities in the different tissues related to respiratory, excretory and reproductive systems of the wistar albino rats. For this respect, 2 different groups each of which contains 6 rats $(n=6)$ were formed as control group and $\mathrm{Wi}-\mathrm{Fi}$ wave administered groups. The rats were necropsied and the different tissues of the rats were extracted. Activities of CA and AChE enzymes were measured for each tissue by using the hydratase, esterase and acetylcholinioidide methods. All the experimental results were provided in mean \pm standard deviation $( \pm$ SD). Statistical significance was identified to be $\mathrm{p}<0.05$. It was observed that there were significant decreases of enzyme activities in wireless administered group in brain, spleen, kidney, and trachea tissues according to CA and AChE levels.

Keywords: Wireless electromagnetic fields; acetylcholinesterase; carbonic anhydrase; enzyme activity; rat

\section{ÖZET}

Çalışmamızın amacı, wistar albino sıçanlarının solunum, boşaltım ve üreme sistemleri ile ilgili farklı dokularda kablosuz (Wi-Fi) dalgaların karbonik anhidraz (CA) ve asetilkolinesteraz (AChE) enzim aktivitelerine etkilerini anlamaktır. Bu bakımdan, her biri 6 sıçan $(n=6)$ içeren 2 farklı grup kontrol grubu ve Wi-Fi dalga uygulanan gruplar olarak oluşturulmuştur. Ratların farklı dokuları çıkarıldı. Her doku için $C A$ ve $A C h E$ enzimlerinin aktiviteleri, hidrataz, esteraz ve asetilkolinioid yöntemleri kullanılarak ölçüldü. Tüm deney sonuçları ortalama \pm standart sapma $( \pm$ SD) olarak sağlandı. İstatistiksel anlamlılık $\mathrm{p}<0.05$ olarak belirlendi. Kablosuz uygulanan grupta beyin, dalak, böbrek ve trakea dokularında CA ve AChE düzeylerine göre anlamlı düşüş olduğu gözlendi.

\section{INTRODUCTION}

There are epidemiological studies in the literature regarding the effects of magnetic fields on cancer, reproduction, and neurobehavior. Lately, newer studies linking the effects of electromagnetic fields to neurological, degenerative, and cardiac diseases have been presented. Moreover, the global increase in the use of smartphones operating in exceeding radio frequencies (RF) 
mustered a significant focus on the possible health effects of electromagnetic radiation (Ann. 2001). Extensive use of wireless fidelity communication devices and their networks significantly increased the exposure of humans to RF fields. Both national and international agencies and organizations have established regulations for the safety of RF fields, yet public anxiety remains on the possibly hazardous effects of such fields to human health. Even though the recent studies were indicated no concise adverse health effects in human health caused from RF exposure, further and detailed studies are recommended to define the health effects caused by RF electromagnetic wave (RF-EMW) exposure to humans more clearly (Habash et al. 2009).

Epigenetic investigations of Radio frequencyElectro magnetic waves (RF-EMW) exposure in some studies were indicated that heat shock proteins (HSPs), ornithine decarboxylase (ODC), p38 mitogen-activated protein kinase (MAPK), cjun, c-myc, p21, Bax, GADD45, Nurr1, etc. are possible reactive proteins and genes to such exposures (Cotgreave IA 2005; Czyz JI et al. 2004; Nikolova T, et al. 2005). Cells exposed to electromagnetic fields (EMF) were analyzed by using quantitative RT-PCR method for transcription level changes in cell cycle regulations, apoptosis and proliferation of cells, cytogenic changes, and in genes responsible for apoptosis, neural genes, and proteins. However, these analyses were revealed no pronounced effects of RF-EMW in mitochondrial functions, nuclear apoptosis, cell proliferation, and chromosomal aberrations (Nikolava T etal. 2005; Bartsch H et al. 2002; Avendaño C. et al. 2012; Poulletier de Gannes F. et al. 2012, Skakkebaek NE. et al. 2006; Deepinder F, 2007; Kundi M. 2004).

Wireless fidelity RF-EMF (Wi-Fi RF-EMF) has found itself a great application in telecommunications with a wide array of devices which has become a standard in modern communications. Therefore, Wi-Fi RF-EMFs are now an everyday part of people using these tools which results in an increasingly high exposure to such fields and absorbing the transmitted energy and thus having increased body temperatures (Pourlis AF 2009; La Vignera S. et al. 2012 a-b; Imai $\mathrm{N}$ et al. 2011; Ribeiro EP et al. 2007; Lee HJ et al. 2010; Dasdag S et al. 2008).

Carbonic anhydrase (CA) family of enzymes are known to be associated with various physiological and pathological processes such as respiratory functions, $\mathrm{pH}$ balance, $\mathrm{CO}_{2}$ hemostasis, electrolyte secretion in tissues, gluconeogenesis, lipogenesis, urea synthesis, bone absorption, calcification, tumorigenesis, etc. Enzymatic inhibitions on these enzymes can be facilitated for the treatments of different diseases like glaucoma, osteoporosis, cancer, obesity, and epilepsy. CA family is among the metalloenzymes, which have $\mathrm{Zn}^{+2}$ ion in their active sites, and catalyzes the slow acting reaction of transition of $\mathrm{CO}_{2}$ to bicarbonate and proton. It's one of the most common enzymes in nature, and first identified in erythrocytes and found to be present in almost all tissues later on (Dasdağ S et al. 1999; Berg JM 2014; Gocer H et al, 2016; Kocyigit UM et al, 2016; Gul H et al, 2016;).

Acetylcholinesterase (AChE, E.C.3.1.1.7) is the principal enzyme for the proper functioning of neural transmission and works to prevent aggregation of active neurotransmitters during the synaptic transmission of nerves by hydrolyzing the acetylcholine (Kocyigit UM et al, 2018; Bhatt, A et al, 2017;Akıncıoğlu A et al. 2017; Göçer H et al. 2014). For Alzheimer's Disease (AD), cholinergic therapeutical agents have acetylcholinesterase inhibitors (AChEI), acetylcholine precursors (ACh), ACh expression facilitators, post-synaptic muscarinic M1 receptor agonists Kose LP et al. 2015; Özbey F et al. 2016; Taslimi P et al. 2016). 


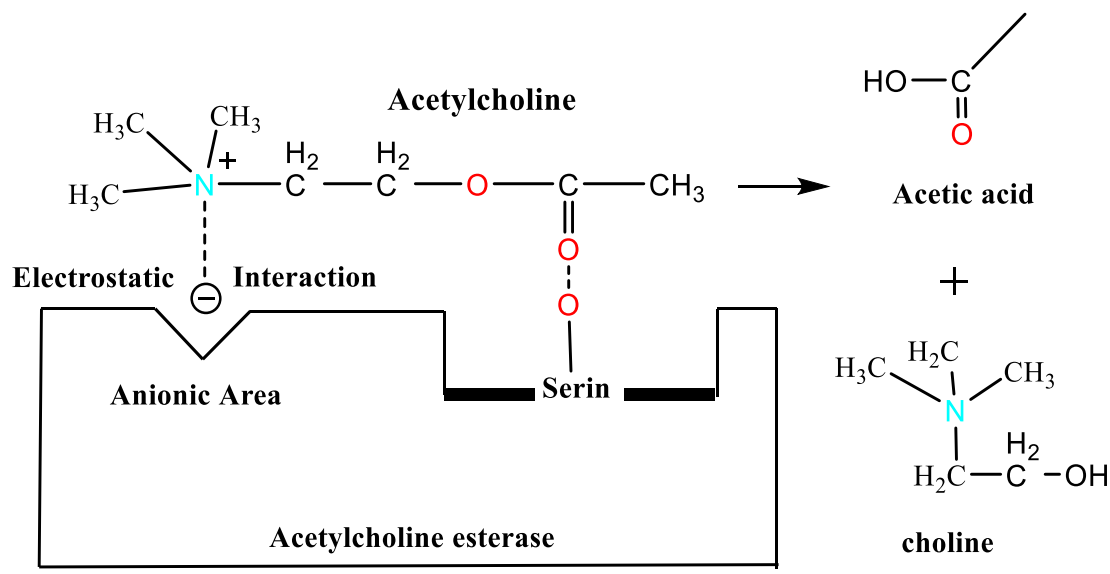

Figure 1. AChE active site and its mechanism.

In the present study, it was aimed to investigate exposure effects of Wi-Fi RF-EMW in CA (I and II) and AChE enzyme activities from tissues of respiratory, excretory, and reproductive systems of rats that were not studied before. Obtained data would provide a scientific contribution to the understanding the effects of Wi-Fi RF-EMW exposure to organisms.

\section{EXPERIMENTAL AND METHODS}

\section{Environmental Conditions of Animal Experiments}

The study was granted approval from the Ethics Committee of the Cumhuriyet University on Experimental Animals (Issue: 06.08.2015/75). Total of 12 adult Wistar albino rats $(180 \pm 10 \mathrm{~g}$ body weight) were used in the study. Rats were housed in standart cages at temperature $24 \pm 2{ }^{\circ} \mathrm{C}$ in Animal Experimentation Unit of Cumhuriyet University Faculty of Medicine in 2018 year. Animal experimentations were conducted in accordance with the Ethical Committee for the Purpose of Control and Supervision of Experiments on Animals according to article writing by Durna Daştan S. et al. 2018. Rats were randomly selected, and divided into two groups $(n=6)$ as Group 1 for control and, Group 2 for Wireless electromagnetic waves exposure (Scozzafava A. et al. 2015; Gülçin I. et al. 2004). A common wireless internet router (Zyxel NBG418N V2 wireless Access Point/Router) was used for Wi-Fi RF-EMW exposure. The router was able to generate RF-EMW field at $2.4 \mathrm{GHz}$ and was working in $300 \mathrm{Mbps}$ transmission. External electromagnetic field pollution was eliminated by placing the router and rat cages inside a Faraday Cage. Rats in Group 2 were exposed to RF-EMW field of $2,4 \mathrm{GHz}$ for 12 hours/day for 21 days.

\section{Homogenisation of Tissues}

Rats were sacrificed 60 minutes after the IP administration of chemicals. Extracted samples were washed three times with using $\mathrm{NaCl}(0.9 \%)$ to clear away the blood and other contaminants. For the preparation of homogenates, samples were first dispersed by the ultra-turrax device which turned samples into extremely small pieces. They were dispersed again in liquid nitrogen, and were homogenized in $3 \mathrm{~mL} / \mathrm{g}$ with $25 \mathrm{mM}$ Tris $\mathrm{HCl}$ $0.1 \mathrm{M} \mathrm{Na}_{2} \mathrm{SO}_{4}$ (pH: 8.7) buffer solution which was centrifuged two times at $20000 \mathrm{rpm}$ for 60 minutes, and subjected to supernatant analyses (Scozzafava A. et al. 2015; Gülçin I. et al. 2004).

\section{Calculation of Carbonic Anhydrase Activity}

\section{Hydratase Activity}

A modified method by Rickli et al. for the measurement for CA enzyme activity was used by measuring hydratase activity (Aksu $\mathrm{K}$ et al. 2016). This modified method has the principle of having the $\mathrm{pH}$ change caused by the $\mathrm{H}^{+}$ion from $\mathrm{CO}_{2}$ hydration is identified by the bromine thymol blue indicator during the time plot. To this end, 1 $\mathrm{mL}$ vernal buffer $(0.025 \mathrm{M}, \mathrm{pH}: 8.2), 0.1 \mathrm{~mL}$ $0.04 \%$ bromine thymol blue, $0.6 \mathrm{~mL}$ purified water and $2.5 \mathrm{~mL} \mathrm{CO}$ solution were added into a blind tube. Thus, the total volume in the activity measurement medium was $4.2 \mathrm{~mL}$. Then, the time elapsed for the blue color of the indicator to turn into the yellowish green $(\mathrm{pH}: 6.3)$, starting from the moment the $\mathrm{CO}_{2}$ solution was added, was measured via a chronometer. $0.05 \mathrm{~mL}$ water was removed and instead, enzyme solution was added into the sample tube, and finally, the time elapsed for the blue color of the indicator to turn into the yellowish green ( $\mathrm{pH}$ : 6.3) as soon as $\mathrm{CO}_{2}$ solution was added $\left(\mathrm{t}_{\mathrm{c}}\right)$ was measured via a chronometer. 
According to this relative activity method, an enzyme unit (EU) was defined as the amount of enzyme that was reduced in time plot compared to $\mathrm{CO}_{2}$ hydration without the enzyme.

\section{Esterase activity}

The principle of method is to hydrolyze the pnitrophenylacetate (PNA), used as a carbonic anhydrase enzyme substrate p-nitrophenolate, providing absorption at $348 \mathrm{~nm}$. Both p-nitro phenol and p-nitrophenolate display the same absorbance at $348 \mathrm{~nm}$ (Kucukoglu K. et al. 2016). Since PNA has very little absorption at this wavelength, it is used as blind (Gul HI. et al. 2016). The procedure was observed for determination of activity measured by using a 1 $\mathrm{mL}$ quartz vessel, per sequence of involvement of the substances forming the reaction mixture into the treatments. Esterase activity was measured by preparing sample tubes containing Tris- $\mathrm{SO}_{4}(0.05$ $\mathrm{M}$; pH: 7.4), PNA, pure water and additional enzyme solution. After preparing the reaction mixture above, the amount of absorbance was checked at 15 seconds intervals and the absorbance difference was calculated by using the absorbance at $348 \mathrm{~nm}$ at $25^{\circ} \mathrm{C}$ after 3 minutes. PNA substrate solution is $3 \mathrm{mM}$, and it is not possible to prepare more concentrated version due to the limited solubility of ester (Gülçin I. et al. 2004).

\section{Measurement of Acetylcholinesterase Activity}

The basis of this method can be described as follows; cholinesterases catalyze the reaction decomposing acetylcholine into thiocolchine and acetaldehyde. Yellow colored 5-thio-2nitrobenzoic acid is formed by the reaction of thiocolchine and DTNB which are obtained as product. Resulting color is measured at $412 \mathrm{~nm}$ (Gülçin I. et al. 2004) The absorbance of the sample and blind vessels was measured at $412 \mathrm{~nm}$ wavelength for 5 minutes. Vessel content was formed with Tris-HCl, Pure water, DTNB, Enzyme solution, and acetylcholinethioiodide for the control tube.

\section{Statistical Analyses}

Results are provided with mean \pm SD. Normal distribution analysis was conducted by the Shapiro-Wilk test. Enzyme data were analyzed by conducting the unpaired $t$ test. Statistical significance was at a p-value of less than 0.05. SPSS v.22 software (IBM, Chicago, IL, USA) was used for the conduction of all statistical analyses.

\section{RESULTS}

Table 1 presents the levels of $\mathrm{CA}$ and AchE enzymes in the selected tissues being relevant with the respiratory, excretory and reproductive systems of rats. There was significant difference between control group and WiFi-RF EMF groups with regard to the CA enzyme levels of trachea, spleen and kidney tissues $(\mathrm{p}<0.05)$. There was no significant difference in the other seven different tissues between control and experimental groups with regard to the CA enzyme levels ( $p>0.05)$. In the trachea, spleen and kidney tissues, the CA enzyme level of WiFi-RF EMF groups were significantly lower than that of control groups $(\mathrm{p}<0.05)$. In the study, the activity of CA enzyme was measured via both esterase and hydratase methods and consistent results were obtained (Fig. 2).

\section{CA Enzyme}

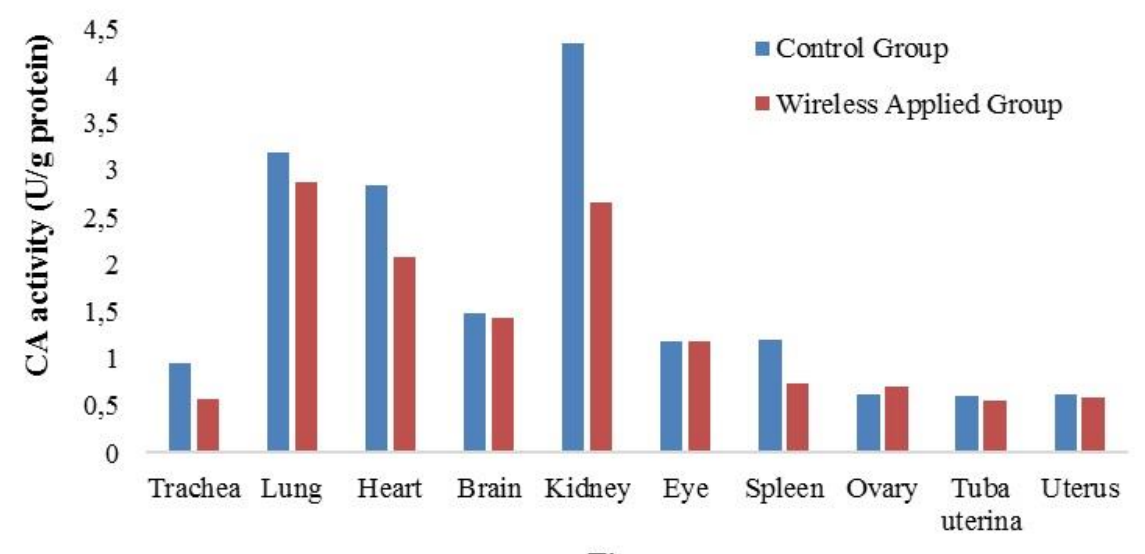

Tissues

Figure 2. The results of carbonic anhydrase (CA) enzyme in different tissues related to respiratory, excretory and reproductive systems of wistar albino rats. 
Table 1. The results of carbonic anhydrase (CA) and, acetylcholinesterase (AChE) enzymes in different tissues related to respiratory, excretory and reproductive systems of wistar albino rats.

\begin{tabular}{|c|c|c|c|c|}
\hline \multirow{2}{*}{$\begin{array}{l}\text { Selected } \\
\text { Tissues of Rat }\end{array}$} & \multicolumn{2}{|c|}{ Carbonic Anhydrase Enzyme } & \multicolumn{2}{|c|}{ AChE Enzyme } \\
\hline & $\begin{array}{c}\text { Control Group }(n=6) \\
\text { Mean } \pm S D\end{array}$ & $\begin{array}{l}\text { Wireless Group }(n=6) \\
\text { Mean } \pm S D\end{array}$ & $\begin{array}{c}\text { Control Group ( } n=6) \\
\text { Mean } \pm \text { SD }\end{array}$ & $\begin{array}{c}\text { Wireless Group }(\mathrm{n}=6) \\
\text { Mean } \pm S D\end{array}$ \\
\hline Trachea & $0.95725 \pm 0.33504$ & $0.56880 \pm 0.07032$ & $0.07025 \pm 0.01363$ & $0.05875 \pm 0.01448$ \\
\hline Lung & $3.18138 \pm 0.91297$ & $2.87962 \pm 1.37202$ & $0.13850 \pm 0.02011$ & $0.12025 \pm 0.04974$ \\
\hline Heart & $2.84163 \pm 0.79514$ & $2.07800 \pm 0.79023$ & $0.13313 \pm 0.05300$ & $0.11312 \pm 0.05491$ \\
\hline Brain & $1.48863 \pm 0.43270$ & $1.43375 \pm 0.61966$ & $0.21525 \pm 0.07614$ & $17232+0028$ \\
\hline Kidney & $4.34343 \pm 0.84250$ & $2.65550 \pm 0.51127$ & $0.19071 \pm 0.04049$ & $0.15688 \pm 0.06520$ \\
\hline Eye & $1.18800 \pm 0.22524$ & $1.19029 \pm 0.63645$ & $0.06983 \pm 0.01507$ & $0.07786 \pm 0.00955$ \\
\hline Spleen & $1.20300 \pm 0.18214$ & $0.72833 \pm 0.05382$ & $0.06675 \pm 0.00908$ & $0.07750 \pm 0.03856$ \\
\hline Ovary & $0.61417 \pm 0.06714$ & $0.69771 \pm 0.35939$ & $0.05913 \pm 0.02245$ & $0.04886 \pm 0.02482$ \\
\hline Tuba uterina & $0.60050 \pm 0.13130$ & $0.55875 \pm 0.13833$ & $0.05200 \pm 0.01717$ & $0.04837 \pm 0.00729$ \\
\hline Uterus & $0.62357 \pm 0.11844$ & $0.58150 \pm 0.17441$ & $0.05425 \pm 0.01258$ & $0.05100 \pm 0.01568$ \\
\hline
\end{tabular}

a,b,c,d $\mathrm{P}<0.05$ vs. controls.

When the activities of acetylcholineesterase enzyme in these selected tissues are evaluated. It was observed that there was a statistically significant difference $(p<0.05)$ between the groups just for the brain tissue. There were no significant differences in the other nine different tissues between control and experimental groups with regard to the AChE enzyme levels (Fig. 3).

AChE Enzyme

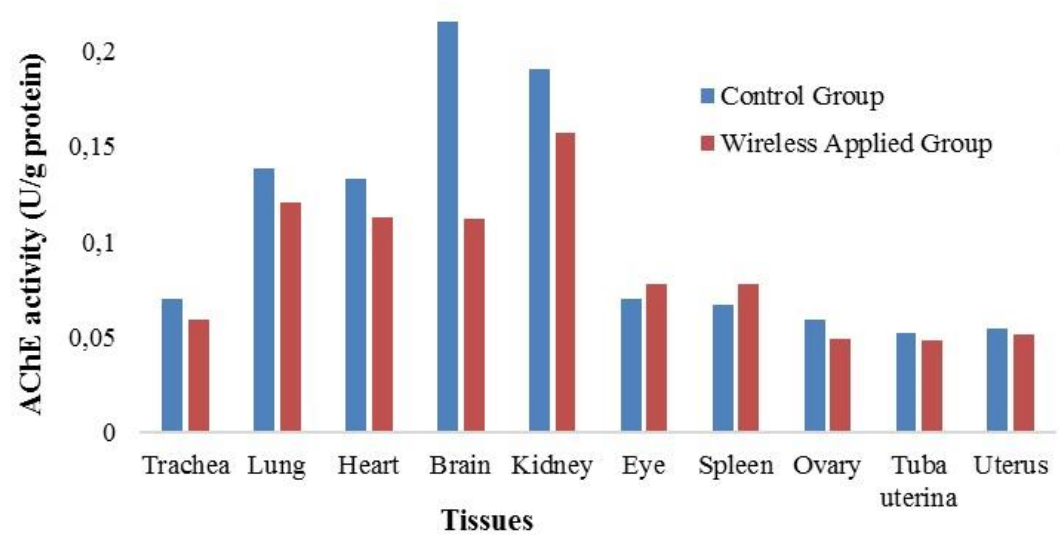

Figure 3. The results of acetylcholinesterase (AChE) enzyme in different tissues related to respiratory, excretory and reproductive systems of wistar albino rats.

Agents and factors that are affecting the functions of $\mathrm{CA}$ and $\mathrm{AChE}$ in different organisms and tissues are interesting research area for the scientist. Limited information is available for the exposure effects of wireless fidelity as a kind of
RF-EMW especially in regards to headaches and cancer. Consequently, improving our understanding in this field is a necessity. The association of parameters used in our study with tissue damage is not certain. Even so, recent studies have demonstrated the relationship 
between oxidative DNA damage (Tunc O., Tremellen K., 2009). We suspected that the continuous exposure to Wi-Fi devices may have more pronounced effects compared with the shorter and intermittent exposure to Wi-Fi. One may suspect that this does not reflect real life conditions, where the duration and intensity of exposure may be more variable.

Limited data are available in the literature for the health risks posed by wireless fidelity waves, and long-term exposure remains a focal point for the human health. Despite the presence of regulations on the safety of RF operated devices, ongoing concerns for public health are still evident especially for the long-term health effects caused by wireless fidelity technology. Hence, the World Health Organization is promoting research on this matter. Notable topics for the investigation of RFEMW exposure are their supposed relation with carcinogenesis, oxidative DNA damage, and tissue level differentiations (Ribeiro EP. et al. 2007).

\section{DISCUSSION}

As the wireless telecommunication technology is growing at a rapid rate and devices operating in such fields are becoming more common, their potential health risks to human health should be taken into account as the occurences and progressions of many kinds of diseases are depending on the exposure of organisms to hazardous compounds and factors. We see the very little study about the effects of WiFi radio frequency wave exposure according to the literature (Atasoy HI. et al. 2013). In this area, more rigorous studies are needed. Various studies have investigated the effects on the human body of RF EMR from mobile phones, within conclusive results, but there have been no studies as yet on the health effects of Wi Fi effects, which are associated with higher frequency radio waves and longer exposure times than the other EMW resource. The out put power of Wi-Fi devices ranges from $20 \mathrm{~mW}$ to $4 \mathrm{~W}$, and is similar to or greater than that of mobile phones, which range from $1 \mathrm{~mW}$ to $2 \mathrm{~W}$ (Lönn $\mathrm{S}$. et al. 2004). Furthermore, they commonly expose the whole body to RF EMR, which generally cause a more uneven and irradiation of all parts of the body. Previous animal studies have not found any significant effect of RF EMR on testicular histology, sperm count and morphology. The researchers studied the effects of RF in the mouse testis and found no significant differences in sperm count and no increase in the percentage of morphologically abnormal sperm in microwaveexposed animals (Cairnie A. B. and Harding. R. K. 1981). Ono T. et al. (2004) could not find any mutagenic effect of $2.45 \mathrm{GHz}$ intermittent whole body RF exposure in the testes of mouse embryos (Ono T. et al. 2004).

Results of the present study demonstrate similarity with some literatures (Kilgallon SJ, Simmons LW. 2005; Makker K, Agarwal A, Sharma R.2009; Tunc O, Tremellen K. 2009). In this study in several tissues of rats, the decreased $\mathrm{CA}$ and AChE activities, though in significant, could imply a partially RF-induced differentiation in enzyme activities. As CA level in trachea, spleen, and kidney tissues and AChE level in brain tissue differ between groups, we can suggest just for these tissues that Wi-Fi can induce oxidative stress, change the CA and AChE enzyme activity and disturb the function and structure of these tissues in rats exposed Wi-Fi waves. In the study, the activity of CA enzyme was measured via both methods and consistent results were obtained. It was observed that there was a statistically significant difference $(\mathrm{p}<0.05)$ between the control group and the Wi-Fi administered group just for three tissue (trachea, spleen, and kidney tissues) and that there was no statistically significant difference for the other seven tissues. When the activities of acetylcholine esterase enzyme in these tissues are evaluated, it was observed that there was a statistically significant difference $(\mathrm{p}<0.05)$ between the control group and the experimental group for just brain tissue. But the other hand, enzyme levels mostly did not differ between our control and Wi-Fi RF groups, in this case we suggest that RF EMR from Wi-Fi did not cause oxidative stress, and didn't change the $\mathrm{CA}$ and $\mathrm{AChE}$ enzyme activity between control and experimental groups in lung, hearth, eye, ovary, tuba uterina, and uterus tissues in rats exposed to the Wi-Fi devices.

\section{CONCLUSION}

CA activity was found to be decreased in trachea, spleen, and kidney tissues collected from Wi-Fi RF-EMW field exposed rats. Significant changes in other tissues and in control group were not detected. AChE enzyme activity was also found to be lower in brain tissues collected from exposed rats as compared to control. In the present study, young rats in their growing periods were used as it was believed that developing organs are more likely to be affected by the RF-EMW exposures as in everyday life, young children are spending much of their time inside such fields both at home 
and in school. The present study was provided with the Wi-Fi exposure effects on enzyme inhibitions, and we believe that further research is necessary to conduct in this subject as wireless fidelity communication is now a significant part of everyday life. It should be noted that, however, exposure to electromagnetic waves fields should be minimized in every possible opportunity.

\section{Acknowledgements}

The authors thank Prof. Dr. Mustafa Turan, Dr. Sinan Soylu and Dr. Ümit M. Koçyiğit for their contribution to this study.

\section{REFERENCES}

1. Akıncıoğlu A. Topal M. Gülçin I. Göksu S. Novel sulphamides and sulphonamides incorporating the tetralin scaffold as carbonic anhydrase and acetylcholine esterase inhibitors. Arch Pharm (Weinheim). 2014; 347(1): 68-76.

2. Akıncıoğlu A. Kocaman E. Akıncıoğlu H. Salmas RE. Durdagi S. Gülçin İ. Supuran CT. Göksu S. The synthesis of novel sulfamides derived from $\beta$ benzylphenethylamines as acetylcholinesterase. butyrylcholinesterase and carbonic anhydrase enzymes inhibitors. Bioorg Chem. 2017; 74: 238-250.

3. Aksu K. Özgeriş B. Taslimi P. Naderi A. Gülçin İ. Göksu S. Antioxidant Activity. Acetylcholinesterase. and Carbonic Anhydrase Inhibitory Properties of Novel Ureas Derived from Phenethylamines. Arch Pharm (Weinheim). 2016; 349 (12): 944-954.

4. Atasoy HI. Gunal MY. Atasoy P. Elgun S. Bugdayci G. Immunohistopathologic demonstration of deleterious effects on growing rat testes of radiofrequency waves emitted from conventional Wi-Fi devices. J Pediatr Urol. 2013; 9 (2): 223-9.

5. Avendaño C. Mata A. Sanchez Sarmiento CA. Doncel GF. Use of laptop computers connected to internet through Wi-Fi decreases human sperm motility and increases sperm DNA fragmentation. Fertil Steril. 2012; 97 (1): 39-45.

6. Bartsch H. Bartsch C. Seebald E. Deerberg F. Dietz K. Vollrath L. Mecke D. Chronic exposure to a GSM-like signal (mobile phone) does not stimulate the development of DMBA-induced mammary tumors in rats: results of three consecutive studies. Radiat Res. 2002; 157 (2): 183-90.

7. Bhatt. A.. Mahon. B. P.. Cruzeiro. V. W. D.. Cornelio. B.. Laronze Cochard. M.. Ceruso. M.. \& Roitberg. A. Structureactivity relationships of benzenesulfonamide based inhibitors towards carbonic anhydrase isoform specificity. Chembiochem. 2017; 18(2): 213-222.

8. Berg JM. Tymoczko JL. Stryer L. Biyokimya. Palme Yayıncilık. P. 2014; 241-247. Ankara.

9. Cairnie A. B. and Harding. R. K. Cytological Studies in Mouse Testis Irradiated with $2.45-\mathrm{GHz}$ ContinuousWave Microwaves. Radiation Research.1981; 87 (1): 100-108.

10. Coban TA. Beydemir Ş. Gülçin İ. Ekinci D. Morphine inhibits erythrocyte carbonic anhydrase in vitro and in vivo. Biological and Pharmaceutical Bulletin 2007; 30 (12): 2257-2261.

11. Cotgreave IA Biological stress responses to radio frequency electromagnetic radiation: are mobile phones really so (heat) shocking? Arch Biochem Biophys. 2005; 435 (1): 227-40.

12. Czyz JI. Guan K. Zeng Q. Nikolova T. Meister A. Schönborn F. Schuderer J. Kuster N. \& Wobus A.M. High frequency electromagnetic fields (GSM signals) affect gene expression levels in tumor suppressor p53-deficient embryonic stem cells. Bioelectromagnetics. 2004, 25 (4): 296-307.

13. Dasdag S. Akdag MZ. Ulukaya E. Uzunlar AK. Yegin D. Mobile phone exposure does not induce apoptosis on spermatogenesis in rats. Arch Med Res. 2008; 39 (1): 40-4.

14. Dasdag S. Ketani MA. Akdag Z. Ersay AR. Sari I. Demirtas OC. Celik MS. Whole-body microwave exposure emitted by cellular phones and testicular function of rats. Urol Res. 1999: 27 (3): 219-23.

15. Deepinder F. Makker K. Agarwal A. Cell phones and male infertility: dissecting the relationship. Reprod Biomed Online. 2007; 15 (3): 266-70.

16. Durna Dastan S. Soylu S. Pence HH. Uyanık B. Duman M. Kurt A. Daştan T. Zılan A. 
turan M Hazardous Genomic Bioeffects of Home Wi-Fi Systems. Neuroquantology. 2018; 16 (11): 172-179.

17. Ekinci Akdemir FN. Albayrak M. Çalik M. Bayir Y. Gülçin İ. The Protective Effects of p-Coumaric Acid on Acute Liver and Kidney Damages Induced by Cisplatin. Biomedicines. 2017; 28(2): 5- 21

18. Gocer H. Topal F. Topal M. Küçük M. Teke D. Gülcin I. Alwasel SH. Supuran CT. Acetylcholinesterase and carbonic anhydrase isoenzymes I and II inhibition profiles of taxifolin. J Enzyme Inhib Med Chem. 2016; 31 (3): 441-7.

19. Gocer H. Akincioğlu A. Göksu S. Gülçin İ. Supuran CT. Carbonic anhydrase and acetylcholinesterase inhibitory effects of carbamates and sulfamoylcarbamates. J Enzyme Inhib Med Chem.2014; 30 (2): 31620.

20. Gul HI. Tugrak M. Sakagami H. Taslimi P. Gulcin I. Supuran CT5. Synthesis and bioactivity studies on new 4-(3-(4Substitutedphenyl)-3a.4-dihydro-3Hindeno[1.2-c]pyrazol-2-yl) benzenesulfonamides. J Enzyme Inhib Med Chem. 2016; 31 (6): 1619-24.

21. Gul H. Mete E. Taslimi P. Gulcin I. Supuran CT. Synthesis. carbonic anhydrase I and II inhibition studies of the 1.3.5-trisubstitutedpyrazolines. J Enzyme Inhib Med Chem. 2016; 32 (1): 189-192.

22. Gülçin I. Beydemir S. Büyükokuroğlu ME. In vitro and in vivo effects of dantrolene on carbonic anhydrase enzyme activities. Biol Pharm Bull. 2004; 27 (5): 613-6.

23. Gulçin İ. Abbasova M. Taslimi P. Huyut Z. Safarova L. Sujayev A. Farzaliyev V. Beydemir Ş. Alwasel SH. Supuran CT. Synthesis and biological evaluation of aminomethyl and alkoxymethyl derivatives as carbonic anhydrase. acetylcholinesterase and butyrylcholinesterase inhibitors. J Enzyme Inhib Med Chem. 2017; 32 (1): 1174-1182.

24. Habash RW. Elwood JM. Krewski D. Lotz WG. McNamee JP. Prato FS Recent advances in research on radiofrequency fields and health: 2004-2007. J Toxicol Environ Health B Crit Rev. 2009; 12 (4): 250-88.

25. Imai N. Kawabe M. Hikage T. Nojima T. Takahashi S. Shirai T. Effects on rat testis of
1.95-GHz W-CDMA for IMT-2000 cellular phones. Syst Biol Reprod Med. 2011; 57 (4): 204-9.

26. Kilgallon SJ. Simmons LW. Image content influences men's semen quality. Biol Lett. 2005; 22 (3): 253-5.

27. Knave B Electromagnetic fields and health outcomes. Ann Acad Med Singapore 2001; 30 (5):489-93.

28. Kocyigit UM. Aslan ON. Gulcin I. Temel Y. Ceylan M. Synthesis and Carbonic Anhydrase Inhibition of Novel 2-(4(Aryl)thiazole-2-yl)-3a.4.7.7a-tetrahydro1H-4.7-methanoisoindole-1.3(2H)-dione Derivatives. Arch Pharm (Weinheim). 2016; 349 (12): 955-963.

29. Kocyigit UM. Budak Y. Gürdere MB. Ertürk F. Yencilek B. Taslimi P. Gülçin İ. Ceylan M. Synthesis of chalcone-imide derivatives and investigation of their anticancer and antimicrobial activities. carbonic anhydrase and acetylcholinesterase enzymes inhibition profiles. Arch Physiol Biochem. 2018; 124 (1): 61-68.

30. Kose LP. Gülçin İ. Goren AC. Namiesnik J. Martinez-Ayala AL. Gorinstein S. LCMS/MS analysis. antioxidant and anticholinergic properties of galanga (Alpinia officinarum Hance) rhizomes. Ind Crops Prod 2015; 74: 712-21.

31. Kucukoglu K. Oral F. Aydin T. Yamali C. Algul O. Sakagami H. Gulcin I. Supuran CT. Gul HI. Synthesis. cytotoxicity and carbonic anhydrase inhibitory activities of new pyrazolines. J Enzyme Inhib Med Chem. 2016, 31 (4): 20-24.

32. Kundi M. Mild K. Hardell L. Mattsson MO. Mobile telephones and cancer--a review of epidemiological evidence. J Toxicol Environ Health B Crit Rev. 2004; 7 (5): 351-84.

33. La Vignera S. Condorelli R. Vicari E. D'Agata R. Calogero AE. Diabetes mellitus and sperm parameters. J Androl. 2012; 33 (2): 145-53. (a)

34. La Vignera S. Condorelli R. Vicari E. D'Agata R. Calogero AE. High frequency of sexual dysfunction in patients with male accessory gland infections. Andrologia. 2012; 1: 438-46. (b) 
35. Lee HJ. Pack JK. Kim TH. Kim N. Choi SY. Lee JS. Kim SH. Lee YS. The lack of histological changes of CDMA cellular phone-based radio frequency on rat testis. Bioelectromagnetics. 2010; 31 (7): 528-34

36. Lönn S. Forssén U. Vecchia P. Ahlbom A. Feychting M. Output power levels from mobile phones in different geographical areas; implications for exposure assessment. Occup Environ Med. 2004, 61 (9): 769-72.

37. Makker K. Agarwal A. Sharma R.Oxidative stress \& male infertility. Indian J Med Res. 2009; 129 (4): 357-67.

38. Nikolova T. Czyz JI. Rolletschek A. Blyszczuk P. Fuchs J. Jovtchev G. Schuderer J. Kuster N. Wobus AM. Electromagnetic fields affect transcript levels of apoptosisrelated genes in embryonic stem cell-derived neural progenitor cells. FASEB J. 2005; 19 (12): 1686-8.

39. Ono T. Saito Y. Komura J. Ikehata H. Tarusawa Y. Nojima T. Goukon K. Ohba Y. Wang J. Fujiwara O. Sato R. Absence of mutagenic effects of $2.45 \mathrm{GHz}$ radiofrequency exposure in spleen. liver. brain. and testis of lacZ-transgenic mouse exposed in utero. Tohoku J Exp Med. 2004; 202 (2): 93-103.

40. Özbey F. Taslimi P. Gülçin İ. Maraş A. Göksu S. Supuran CT. Synthesis of diaryl ethers with acetylcholinesterase. butyrylcholinesterase and carbonic anhydrase inhibitory actions. J Enzyme Inhib Med Chem. 2016; 31: 79-85.
41. Poulletier de Gannes F. Billaudel B. Haro E. Taxile M. Le Montagner L. Hurtier A. Ait Aissa S. Masuda H. Percherancier Y. Ruffié G. Dufour P. Veyret B. Lagroye I. Rat fertility and embryo fetal development: influence of exposure to the Wi-Fi signal. Reprod Toxicol. 2012; 36: 1-5.

42. Pourlis AF. Reproductive and developmental effects of EMF in vertebrate animal models. Pathophysiology. 2009; 16 (2-3): 179-89.

43. Ribeiro EP. Rhoden EL. Horn MM. Rhoden C. Lima LP. Toniolo L. Effects of subchronic exposure to radio frequency from a conventional cellular telephone on testicular function in adult rats. J Urol. 2007; 177 (1): 395-9.

44.Scozzafava A. Kalın P. Supuran CT. Gülçin İ. Alwasel SH. The impact of hydroquinone on acetylcholine esterase and certain human carbonic anhydrase isoenzymes (hCA I. II. IX. and XII). J Enzyme Inhib Med Chem. 2015; 30 (6): 941-6.

45.Skakkebaek NE. Jørgensen N. Main KM. Rajpert-De Meyts E. Leffers H. Andersson AM. Juul A. Carlsen E. Mortensen GK. Jensen TK. Toppari J. Is human fecundity declining?. Int J Androl. 2006; 29 (1): 2-11.

46. Taslimi P. Gulcin I. Ozgeris B. Goksu S. Tumer F. Alwasel SH. Supuran CT. The human carbonic anhydrase isoenzymes I and II (hCA I and II) inhibition effects of trimethoxyindane derivatives. J Enzyme Inhib Med Chem. 2016; 31 (1): 152-7.

47.Tunc O. Tremellen K. Oxidative DNA damage impairs global sperm DNA methylation in infertile men. J Assist Reprod Genet. 2009; 26 (9-10): 537-44 